\title{
Metabolic And Biochemical Changes Associated With Root Growth Restriction Under Cd Stress During Maize Pre-Emergence
}

\section{Carolina L. Matayoshi}

Universidad de Buenos Aires Facultad de Farmacia y Bioquimica

Liliana B. Pena ( $\square$ lpena@ffyb.uba.ar)

Universidad de Buenos Aires Facultad de Farmacia y Bioquimica https://orcid.org/0000-0002-84006674

\section{Vicent Arbona}

Universitat Jaume I - Campus de Riu Sec

\section{Aurelio Gómez-Cadenas}

Universitat Jaume I - Campus de Riu Sec

\section{Susana M. Gallego}

Universidad de Buenos Aires Facultad de Farmacia y Bioquimica

\section{Research Article}

Keywords: Zea mays L., Heavy metals, Phytohormones, Protein carbonylation

Posted Date: June 14th, 2021

DOI: https://doi.org/10.21203/rs.3.rs-565738/v1

License: (c) (i) This work is licensed under a Creative Commons Attribution 4.0 International License. Read Full License 


\section{Abstract}

Cadmium (Cd) pollution of agricultural soils is a growing global problem. Plant growth restriction is the main visible symptom of $\mathrm{Cd}$ toxicity, and this metal may be particularly harmful to the preformed, seminal root during the pre-emergence stage. In the present study, we focused on Cd phytotoxicity on seminal root growth, nutrient composition, redox status, and hormone homeostasis during the preemergence stage, distinguishing between the root apex and the remaining root tissue. After $72 \mathrm{~h}$ of metal exposure (50 and $100 \mu \mathrm{M} \mathrm{CdCl}_{2}$ ), root length and biomass was diminished, as well as $\mathrm{Ca}, \mathrm{Fe}, \mathrm{Mg}$, and $\mathrm{Mn}$ contents. A redox imbalance was evidenced by changes in peroxidase activities and decreased ascorbate-dehydroascorbate ratio in both root parts. There was less accumulation of carbonylated proteins in both root fractions upon exposition to $50 \mu \mathrm{M} \mathrm{Cd}$, compared to $100 \mu \mathrm{M} \mathrm{Cd}$, and this was related to increased $20 \mathrm{~S}$ proteasome activities. Cd incremented ABA, IAA, and SA contents, but drastically reduced the biologically active gibberellin GA4 and the conjugate jasmonoyl isoleucine (JA-lle). We demonstrated that the whole root tissue is involved in maize response to $\mathrm{Cd}$ stress, which entails redox and hormonal rearrangements, probably directed to widen plant defense lines at the expense of root growth.

\section{Highlights}

-Cd reduced maize root growth during pre-emergence and altered its mineral composition.

-Cd disrupted ascorbate homeostasis in the root apex and the remaining root tissue.

-Cd induced CAT and GPX activities and reduced GA4 and JA-lle contents.

- Less carbonylated proteins accumulated at $50 \mu \mathrm{M}$ Cd compared to $100 \mu \mathrm{M} \mathrm{Cd}$.

- 20S proteasome activity was induced 48 and $72 \mathrm{~h}$ after $50 \mu \mathrm{M} \mathrm{Cd}$ exposure (whole root).

\section{Introduction}

Cadmium is a transition metal ion released to the environment by industrial activities and urbanization. In cultivated soils, Cd derives mainly from P fertilizers (Sterckeman et al. 2018). Due to its relatively high mobility and high toxicity for living organisms-even at very low doses-, cadmium is considered a particularly dangerous pollutant (Vardhan et al. 2019). The increasing contamination of soil and food crops represents a serious global problem nowadays (Rehman et al. 2018; Dala-Paula et al. 2018; Cai et al. 2019). Plant growth restriction is one of the main visible symptoms related to Cd phytotoxicity (Gallego et al. 2012). Despite being a redox-inactive metal, Cd toxicity has been in part associated with oxidative stress production (Gallego y Benavides 2019).

It is known that plant growth regulation and plant responses to stress depend on the interplay between hormonal and redox balances (Santner y Estelle 2009; De Tullio et al. 2010; Bartoli et al. 2013). Plant 
hormones comprise a series of natural compounds required in low concentrations to fulfill their function. While each plant hormone has its specific pathway that acts in a non-redundant way, their activities are interconnected by a complex network, and it is the interaction and cooperation between hormones that dynamically regulate plants' development and physiology (Vanstraelen y Benková 2012). It has been described that the exogenous application of phytohormones reduces the toxic effects of metals, in part through the improvement of the cell antioxidant potential (Singh et al. 2016).

On the other hand, it is known that plant cell redox homeostasis is controlled by a complex system known as the Foyer-Halliwell-Asada pathway, responsible for reactive oxygen species (ROS) scavenging (Foyer y Noctor 2011). This antioxidant defense machinery includes enzymes and low molecular weight compounds, like glutathione (GSH) and ascorbic acid (ASC) (Foyer y Noctor 2016). Nevertheless, an excessive ROS production that overwhelms the protective antioxidant mechanism can occur when plants are subjected to adverse environmental conditions (Gill y Tuteja 2010). A consequence of cell redox imbalance is protein oxidative damage, commonly expressed by carbonyl group increases (Møller et al. 2007). Carbonylated proteins can form high-molecular-weight aggregates that compromise several cellular functions (Nyström 2005). Because protein carbonylation is a covalent, non-reversible modification, oxidatively damaged proteins have to be rapidly degraded, mainly by the 20S proteasome activity in the cytoplasm and nucleus (Pena et al. 2007; Polge et al. 2009).

Maize (Zea mays L.) is one of the most important crops used for human and animal diet in the world (Godfray et al. 2010), and in some cases, maize-producing lands are at high risk of cadmium contamination (Chumbley y Unwin 1982; Dharma-Wardana 2018). It has been reported that Cd reduces growth, induces chlorosis, alters chloroplast ultrastructure, produces oxidative damage, modifies cell wall composition, and affects polyamine metabolism in maize plants (Anjum et al. 2015; Vatehová et al. 2016; Seifikalhor et al. 2020). Also, previous data indicate that maize plants tend to retain and accumulate cadmium at the root level (Anjum et al. 2015; Vatehová et al. 2016), where ROS production is induced soon after metal exposure (Liu et al. 2019).

The emergence of maize coleoptile from the soil surface delimits the onset of plant phototrophic lifestyle and takes place at 5 to 7 days after planting under favorable, natural conditions (Abendroth et al. 2011). The embryonically preformed root type dominates during this stage of development (Hochholdinger 2009). Apart from being vital for the vigor of young maize plants during the first weeks after germination, the embryonic root system is the first plant organ expected to interact with the underground environment and eventually suffer the toxic effects caused by Cd present in soils (Tai et al. 2016). Several reports indicate a higher $\mathrm{Cd}^{2+}$ influx in the root tip region, even when cadmium acquisition could be achieved through the entire root utilizing metal transporters. Direct xylem loading due to the lack of Caspary band and higher expression of transport systems associated with $\mathrm{Cd}$ uptake located close to the root tip have been related to this phenomenon (Piñeros et al. 1998; Laporte et al. 2013; Chen et al. 2018). Thus, the root apex could be the main site prone to suffer the toxic effects of metal ions. 
In this work, the impact of $\mathrm{Cd}$ on the nutrient composition, redox balance, and phytohormone profile of embryonic maize roots was analyzed, distinguishing between the first $5 \mathrm{~mm}$ from the root tip, considered the root apex (Ap), and the remaining root tissue (Rt). Because plants are still under a chemoheterotrophic lifestyle at the pre-emergence stage, our analysis lets aside the well-known effects of cadmium on photosynthesis.

\section{Materials And Methods}

\subsection{Plant material and growing conditions}

Seeds of maize (Zea mays L. cv 2741MGRR2 kindly provided by DON MARIO Semillas, Buenos Aires, Argentina) were imbibed and germinated on filter paper in a plastic box containing deionized water for 72 h. Then, uniformly developed seedlings with primary roots of approximately $1.5 \mathrm{~cm}$ length were carefully transferred to a hydroponic system containing $250 \mathrm{~mL}$ of diluted $(1 / 10)$ Hoagland's nutrient solution (Hoagland y Aron 1950) without (control, C) or with 50 or $100 \mu \mathrm{M} \mathrm{CdCl}_{2} ; 30$ seedlings were distributed in each container. Cd speciation was calculated with Visual MINTEQ ver. 3.1 (J P Gustafssons, KTH, Sweden). In the nutrient solution containing $100 \mu \mathrm{M}$ of $\mathrm{Cd}$, about $88 \%$ was in $\mathrm{Cd}^{2+}$ form, the most phytoavailable. Plants were grown in a controlled climate room at $24 \pm 2^{\circ} \mathrm{C}$. All the experiments were carried out in the darkness to mimic soil conditions during germination and post-germinative growth. After $72 \mathrm{~h}$ of treatment, roots were gently washed with distilled water. The tissue collected from each container was considered a biological replicate. Root length, fresh weight (FW), and dry weight (DW, determined after drying the roots at $80^{\circ} \mathrm{C}$ until constant weight) were measured. Also, dried root powder was used to determine $\mathrm{Cd}$ and nutrient content. Determinations were performed in parallel using root apical segments obtained from the first $5 \mathrm{~mm}$ from the tip (Ap) or all the remaining root tissue (Rt).

\subsection{Nutrient composition of maize roots}

Elemental analysis was performed at the Spectrometry Core Facility INQUISAL, Universidad Nacional de San Luis (UNSL-CONICET). Briefly, dried root powder $(50 \mathrm{mg})$ was homogenized in $1 \mathrm{~mL}$ of $65 \%(\mathrm{v} / \mathrm{v})$ $\mathrm{HNO}_{3}$ in an ultrasonic bath during $30 \mathrm{~s}$. Then, $0.5 \mathrm{~mL}$ of $\mathrm{H}_{2} \mathrm{O}_{2}$ was added, and the mixture was incubated for $1 \mathrm{~h}$ at $60^{\circ} \mathrm{C}$ in a thermostatic bath. After diluting the samples with ultrapure water, inductively coupled plasma mass spectrometry (ICP-MS) (Perkin Elmer Elan DRC) was applied to estimate Cd, $\mathrm{Cu}, \mathrm{Ca}, \mathrm{Fe}, \mathrm{K}$, $\mathrm{Mg}, \mathrm{Mn}, \mathrm{P}, \mathrm{S}$, and $\mathrm{Zn}$ content.

\subsection{Enzymatic and non-enzymatic antioxidants}

Protein extracts were prepared from $0.1 \mathrm{~g}$ of fresh tissue homogenized in $1 \mathrm{~mL}$ of $50 \mathrm{mM}$ phosphate buffer ( $\mathrm{pH} 7.4)$ containing $1 \mathrm{mM}$ EDTA and $0.5 \%(\mathrm{v} / \mathrm{v})$ Triton $\mathrm{X}-100$, at $4^{\circ} \mathrm{C}$. The homogenates obtained centrifuged at $13,000 \times \mathrm{g}$ for $30 \mathrm{~min}$ at $4^{\circ} \mathrm{C}$, and the supernatants were used for the assays. Protein content was estimated according to Bradford (1976). 
The activity of catalase (CAT, EC 1.11.1.6), guaiacol peroxidase (GPX, EC 1.11.1.7), and ascorbate peroxidase (APX, EC 1.11.1.11) were measured as described previously (Nakano y Asada 1981; Aebi 1984). CAT content was expressed in pmol mg-1 and calculated using $\mathrm{k}=4.7 \times 10^{-7} \mathrm{M}^{-1} \mathrm{~s}^{-1}$. One unit of GPOX was defined as the amount of tetraguaiacol formed ( $\mathrm{mmol}$ ) per min, and one unit of APOX was defined as mmoles of oxidized ascorbate per min.

Ascorbate (ASC) and dehydroascorbate (DHAs) were determined as described by Law et al. (1983). Extracts were obtained by homogenizing $0.1 \mathrm{~g}$ of root tissue in $1 \mathrm{~mL}$ of $0.1 \mathrm{~N} \mathrm{HCl}$. After centrifugation $\left(13,000 \times \mathrm{g}, 30 \mathrm{~min}\right.$, at $\left.4^{\circ} \mathrm{C}\right)$, the supernatants were used for the assays. A standard curve of commercial ASC was used for calibration.

\subsection{Quantitative dot blot analysis of carbonylated proteins}

Protein extracts were prepared by homogenizing $0.1 \mathrm{~g}$ of root tissue in $0.5 \mathrm{~mL}$ of loading buffer $(60 \mathrm{mM}$ Tris- $\mathrm{HCl}(\mathrm{pH} 6.8), 5 \%(\mathrm{v} / \mathrm{v}) \beta$-mercaptoethanol). After centrifugation at $26,000 \mathrm{xg}$ for $15 \mathrm{~min}$ at $4{ }^{\circ} \mathrm{C}$ and protein derivatization with 2,4-dinitrophenylhydrazine (2,4-DNPH) dot blot analysis was performed as described Weher and Levine (2012). Membranes were photographed and then analyzed with Gel-Pro software, and the amount of oxidized proteins was expressed as arbitrary units (assuming control value equal to 100 units), based on the absolute integrated optical density of each dot.

\subsection{Proteasome activities}

Proteasome activity in root tissue was determined as described by Kim et al. (2003). Protein extracts were prepared in $135 \mathrm{mM}$ Tris-acetate buffer (pH 7.5) containing $12.5 \mathrm{mM} \mathrm{KCl}, 80 \mu \mathrm{M} \mathrm{EGTA}, 6.25 \mathrm{mM} 2-$ mercaptoethanol, and $0.17 \%(\mathrm{w} / \mathrm{v}$ ) octyl- $\beta$-D-glucopyranoside. After homogenizing $100 \mathrm{mg}$ of root tissue (Ap or $\mathrm{Rd}$ ) in $0.5 \mathrm{~mL}$ buffer, the extracts were centrifuged at $6,400 \mathrm{~g}$ for $30 \mathrm{~min}$ at $4^{\circ} \mathrm{C}$, and the supernatants were further used to determine chymotrypsin-like (Q), trypsin-like (T), and peptidylglutamylpeptide hydrolase (PGPH) activities (Matayoshi et al. 2020). Due to the extraction buffer interference with Bradford reaction, protein content was determined by the method of Lowry et al. (1951).

\subsection{Plant hormone analysis}

Hormone extraction and analysis were carried out as described in Durgbanshi et al. (2005), with few modifications (Matayoshi et al. 2020). Absolute levels of hormones (indole-3-acetic acid, IAA; abscisic acid, ABA; salicylic acid, SA; jasmonic acid, JA; jasmonoyl isoleucine, JA-lle, and gibberellins, GA3, 4, 7, 20) were determined using an ultra-performance liquid chromatography system (Acquity SDS, Waters Corp., Milford, MA, USA or Waters Alliance 2695, Waters Corp.) coupled to a triple quadrupole mass spectrometer (TQS, Micromass Ltd., UK). All data were acquired in negative electrospray mode and processed using MassLynx v4.1 software. Quantitation was achieved after external calibration with standards of known amount and referenced to actual sample weight.

\subsection{Statistical analysis}


Each container had 30 seeds from which $0.1 \mathrm{~g}$ of tissue was collected and considered as a biological replicate. Tables and figures show means \pm SEM of three or five independent experiments, with three biological replicates per treatment. Differences among treatments were analyzed by 1-way ANOVA, taking $P<0.05$ as significant, followed by Tukey's multiple comparisons test

\section{Results And Discussion}

\subsection{Cadmium accumulation reduced maize root growth and modified root nutrient composition}

The presence of $\mathrm{Cd}$ in the hydroponic solution reduced maize root growth by about $70 \%$ in length and 45\% in biomass (Table 1), in line with previous reports (Xu et al. 2014; Anjum et al. 2016b; Li et al. 2020a), and $\mathrm{Cd}$ accumulation in maize root was clearly dose-dependent (Fig. 1). However, a similar degree of growth impairment was observed under both Cd concentrations tested. Laboratory soil-less systems abolish the complex physicochemical interactions that take place under natural field conditions and may alter nutrients' and pollutants' bioavailability. Among the soil properties that govern Cd diffusion flux towards the root surface, soil pH, clay content, metal oxides, cation exchange capacity, organic matter content, and $\mathrm{Ca}^{2+}$ concentration have been reported, and also total $\mathrm{Cd}$ content impacts on Cd uptake (Liu et al. 2015a; Lin et al. 2016; Yi et al. 2020).

Table 1

Effect of $\mathrm{Cd}$ on root length and biomass. Maize seedlings were grown in a hydroponic system containing diluted (1/10) Hoagland's nutrient solution without (control, C) or with 50 and $100 \mu \mathrm{M}$ of $\mathrm{CdCl}_{2}$, and root length, fresh weight (FW), and dry weight (DW) were determined $72 \mathrm{~h}$ later.

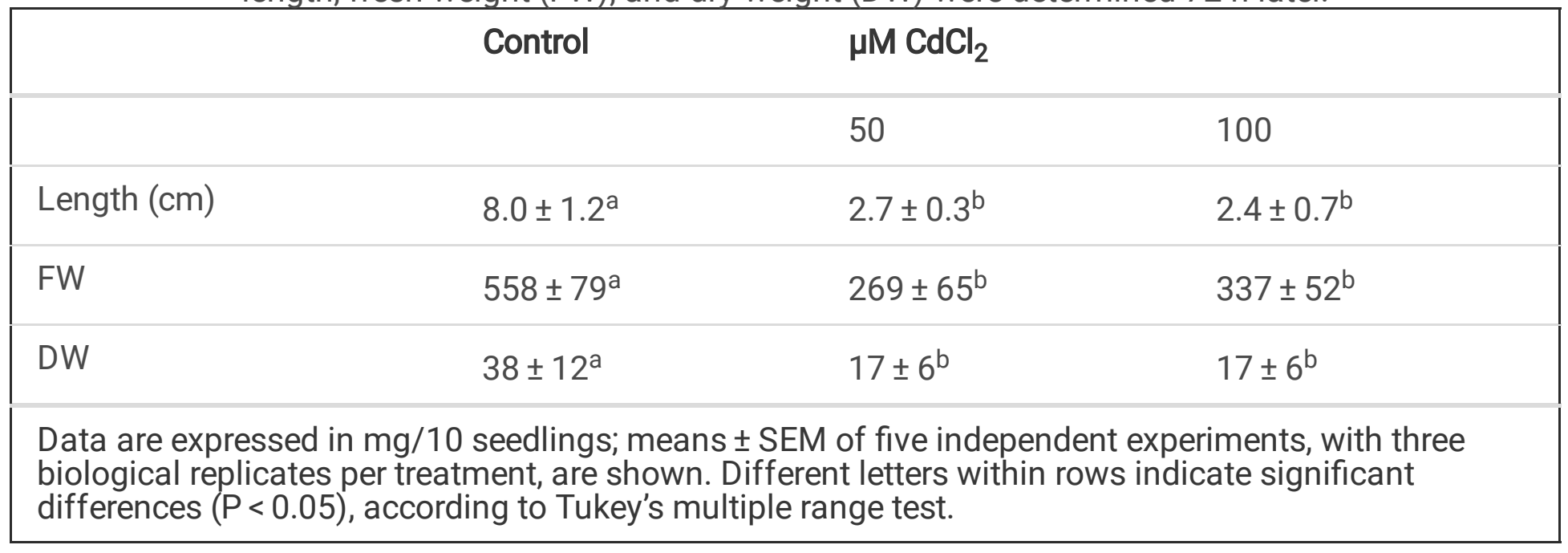

Plants have not developed any specialized uptake system for cadmium because this element has no biological function. Nevertheless, this metal can be easily taken up by plant roots through membrane transporters of essential nutrients (Sterckeman y Thomine 2020). Current evidence indicates that Cd root symplastic influx in maize is controlled by high- and low-affinity transport systems (Redjala et al. 2009, 2010). Furthermore, cadmium can be strongly adsorbed on the maize cell wall, resulting in a large amount of $\mathrm{Cd}^{2+}$ being retained in the root apoplast (Redjala et al. 2009). 
As Table 2 shows, Cd accumulation in emerging maize roots was accompanied by significant decreases in $\mathrm{Ca}, \mathrm{Fe}, \mathrm{Mg}$, and $\mathrm{Mn}$ contents. A reduction of $48 \%$ and $68 \%$ in Ca level was determined for 50 and 100 $\mu \mathrm{M} \mathrm{Cd}$, respectively. For both $\mathrm{Cd}$ concentrations assayed, the reduction in $\mathrm{Mg}$ level was close to $60 \%$, and for Fe and $\mathrm{Mn}$, similar decreases of about $38 \%$ were detected. On the other hand, $\mathrm{Zn}$ was incremented by $16 \%$ over the control only under $50 \mu \mathrm{M} \mathrm{Cd}$, and Cu content doubled that of the control in the roots of seedlings subjected to $100 \mu \mathrm{M}$ Cd.

Table 2

Effect of Cd on root chemical composition. Maize seedlings were grown in a hydroponic system containing diluted (1/10) Hoagland's nutrient solution without (control, C) or with 50 and $100 \mu \mathrm{M}$ of $\mathrm{CdCl}_{2}$. After $72 \mathrm{~h}$ of treatment, roots were harvested and used for analytical determinations. Element concentrations are expressed in $\mathrm{mg} \mathrm{kg}^{-1}$ of dry weight.

\begin{tabular}{|c|c|c|c|c|c|c|c|c|c|}
\hline & $\mathrm{Cu}$ & $\mathrm{Ca}$ & $\mathrm{Fe}$ & $\mathrm{K}$ & $\mathrm{Mg}$ & $\mathrm{Mn}$ & $\mathbf{P}$ & $S$ & $\mathrm{Zn}$ \\
\hline C & $\begin{array}{l}30 \pm \\
10^{\mathrm{b}}\end{array}$ & $\begin{array}{l}2135 \pm \\
326^{a}\end{array}$ & $\begin{array}{l}79 \pm \\
09^{a}\end{array}$ & $\begin{array}{l}15367 \pm \\
1436^{\mathrm{a}}\end{array}$ & $\begin{array}{l}1372 \pm \\
460^{a}\end{array}$ & $\begin{array}{l}8 \pm \\
1^{\mathrm{a}}\end{array}$ & $\begin{array}{l}9871 \pm \\
420^{a}\end{array}$ & $\begin{array}{l}1688 \pm \\
398^{a}\end{array}$ & $\begin{array}{l}59 \pm \\
1^{b}\end{array}$ \\
\hline $\begin{array}{l}50 \\
\mu \mathrm{M}\end{array}$ & $\begin{array}{l}35 \pm \\
4^{b}\end{array}$ & $\begin{array}{l}1103 \pm \\
94^{b}\end{array}$ & $\begin{array}{l}49 \pm \\
3^{b}\end{array}$ & $\begin{array}{l}19474 \pm \\
1611^{a}\end{array}$ & $525 \pm 9^{b}$ & $\begin{array}{l}5 \pm \\
1^{\mathrm{b}}\end{array}$ & $\begin{array}{l}10868 \pm \\
165^{a}\end{array}$ & $\begin{array}{l}1723 \pm \\
124^{\mathrm{a}}\end{array}$ & $\begin{array}{l}69 \pm \\
4^{a}\end{array}$ \\
\hline $\begin{array}{l}100 \\
\mu \mathrm{M}\end{array}$ & $\begin{array}{l}73 \pm \\
9^{a}\end{array}$ & $\begin{array}{l}700 \pm \\
49^{b}\end{array}$ & $\begin{array}{l}50 \pm \\
2^{b}\end{array}$ & $\begin{array}{l}17927 \pm \\
178^{a}\end{array}$ & $\begin{array}{l}654 \pm \\
12^{\mathrm{b}}\end{array}$ & $\begin{array}{l}5 \pm \\
1^{\mathrm{b}}\end{array}$ & $\begin{array}{l}9299 \pm \\
268^{a}\end{array}$ & $\begin{array}{l}1644 \pm \\
196^{\mathrm{a}}\end{array}$ & $\begin{array}{l}55 \pm \\
2^{b}\end{array}$ \\
\hline
\end{tabular}

Change in nutrient absorption/distribution patterns is one of the most recognized cadmium harmful effects and has been mainly attributed to competition with divalent cation transporters (Huang et al. 2020). Ca and $\mathrm{Mg}$ (typically the most abundant divalent cations in plants) reductions could have affected normal growth and development. In this sense, it has been pointed out that growth restriction under $\mathrm{Cd}$ stress would be a nutrient deficiency symptom and the result of homeostatic balance loss between these cations (Tang y Luan 2017; Thor 2019; Kleczkowski y Igamberdiev 2021). Similarly, Cd reduced Fe and Mn contents in maize root. According to several reports, $\mathrm{Cd}$ shares similar plant entry routes with these relevant nutrients, so that the decreases found can be the outcome of Cd competition with Fe and $\mathrm{Mn}$ transporters (Thomine et al. 2000; Wu et al. 2016; Chen et al. 2017b; Chang et al. 2020). On the other hand, it has been demonstrated that the external addition of $\mathrm{Ca}, \mathrm{Mg}, \mathrm{Fe}$, or $\mathrm{Mn}$ to the nutrient solution restricted Cd uptake and translocation, resulting in alleviation of Cd stress (Pal'ove-Balang et al. 2006; Sterckeman et al. 2011; Liu et al. 2013; Kudo et al. 2015; Rahman et al. 2016; Huang et al. 2017; Chen et al. 2017a; Hussain et al. 2020).

A complex interaction between $\mathrm{Cd}$ and $\mathrm{Zn}$ has been documented before, and it was proposed that uptake/translocation of $\mathrm{Zn}$ would increase in the presence of $\mathrm{Cd}$ (Nan et al. 2002). Moreover, it was demonstrated that induction of several genes belonging to the ZIP family-a group of proteins that 
mediate $\mathrm{Zn}$ and $\mathrm{Cd}$ transport-depends on the Zn:Cd ratio in the growing medium (Barabasz et al. 2016; Palusińska et al. 2020).

$\mathrm{Cu}$ increase and $\mathrm{Mn}$ decrease could account for cell redox homeostasis disruption under $\mathrm{Cd}$ stress. $\mathrm{Cu}$ is a redox-active metal and Mn, apart from having free radical scavenging capacity (Coassin et al. 1992), acts as a cofactor of an important enzymatic antioxidant, superoxide dismutase (Mn-SOD); Ca is also a signaling messenger intimately interconnected with ROS (Mazars et al. 2010; Steinhorst y Kudla 2013). Thus, the nutrient imbalance could be part of the indirect mechanisms by which $\mathrm{Cd}$ induces oxidative stress in maize roots.

\subsection{Cadmium differentially affected peroxidase activities along the root and disrupted ascorbate homeostasis}

In maize seminal root, CAT and APX activities were mostly localized in the root tip (Ap), while GPX activity was predominantly in the remaining tissue (Rt) (Fig. 2). Among peroxidases, CAT catalyzes the dismutation of $\mathrm{H}_{2} \mathrm{O}_{2}$ in the absence of electron donors. Its activity is largely found in subcellular compartments with $\mathrm{H}_{2} \mathrm{O}_{2}$ generation, such as peroxisomes, and also in mitochondria, chloroplasts, and the cytosol (Sharma y Ahmad 2014). CAT activity increased in the Ap under $100 \mu \mathrm{M} \mathrm{Cd}^{2+}(130 \%$ over the control), but in the Rt, CAT activity increased by $67 \%$ under $50 \mu \mathrm{M} \mathrm{Cd}^{2+}$ and decreased by $42 \%$ under 100 $\mu \mathrm{M} \mathrm{Cd}^{2+}$ compared to the control. An increase in CAT activity may be interpreted as a cell-protective strategy against the detrimental effect of $\mathrm{H}_{2} \mathrm{O}_{2}$. On the contrary, a decrease in CAT activity deprives cells of their normal antioxidant capacity and results in oxidative stress. Catalase inactivation by metals has been associated with the oxidation of the protein structure (Pena et al. 2011) and the suppression of CAT gene expression (Ye et al. 2014).

To counteract an excessive $\mathrm{H}_{2} \mathrm{O}_{2}$ formation in plant tissues, non-specific peroxidases acting on one- or two-electron donors (including phenolic compounds such as guaiacol) are usually induced. In plants, GPX activity is mainly located in vacuoles and cell walls but not in organelles (Asada 1992). Under both concentrations, Cd increased GPX activity by about $70 \%$ in the Ap, while in the Rt, increases over the control of $47 \%$ and $72 \%$ for 50 and $100 \mu \mathrm{M} \mathrm{Cd}^{2+}$, respectively, were recorded (Fig. 2). GPX activity rise during $\mathrm{Cd}$ stress would be involved not only in the control of $\mathrm{H}_{2} \mathrm{O}_{2}$ levels but also in the modulation of plant growth and development through the control of hormonal and cell wall metabolism (Jouili et al. 2011).

Ascorbate peroxidase reduces $\mathrm{H}_{2} \mathrm{O}_{2}$ to $\mathrm{H}_{2} \mathrm{O}$ using ascorbate as the specific electron donor. Different APX isoforms are located in chloroplasts, cytosol, mitochondria, and peroxisomes, as well as in the apoplastic space (Gill y Tuteja 2010; Hasanuzzaman et al. 2019). In maize root apex, APX activity was not affected by $\mathrm{Cd}$ treatment, in line with previous observations in barley root tips (Bocova et al. 2012), but the activity of this enzyme was particularly impaired in the Rt, dropping to near to half under both $\mathrm{Cd}$ concentrations (Fig. 2). Because of a higher APX affinity for $\mathrm{H}_{2} \mathrm{O}_{2}$ than CAT and GPX, it has been suggested that this 
enzyme has a more crucial role in the scavenging of ROS during abiotic stress (Sofo et al. 2015; Anjum et al. 2016a).

In both root portions, total ASC (ASC plus DHAs) levels augmented under Cd treatment due to a pronounced rise in DHAs content, resulting, at the same time, in the reduction of ASC/DHAs ratio (Table 3). This finding suggests that $\mathrm{Cd}$ altered the adequate functioning of the ASC-GSH cycle.

Table 3

Effect of Cd on ascorbate (ASC) and dehydroascorbate (DHAs) content. Maize seedlings were grown in a hydroponic system containing diluted (1/10) Hoagland's nutrient solution without (control, C) or with 50 and $100 \mu \mathrm{M}$ of $\mathrm{CdCl}_{2}$ for $72 \mathrm{~h}$. Concentrations are expressed in nmol g-1 of fresh weight.

\begin{tabular}{|c|c|c|c|c|c|c|}
\hline & Ap & & & Rt & & \\
\hline & ASC & DHAs & ASC / DHAs & ASC & DHAs & ASC / DHAS \\
\hline C & $218 \pm 10^{a}$ & $475 \pm 31^{c}$ & 0.5 & $915 \pm 50^{A}$ & $310 \pm 60^{B}$ & 2.9 \\
\hline $50 \mu \mathrm{M}$ & $248 \pm 5^{a}$ & $2265 \pm 81^{a}$ & 0.1 & $1090 \pm 20^{A}$ & $590 \pm 40^{\mathrm{B}}$ & 1.8 \\
\hline $100 \mu \mathrm{M}$ & $151 \pm 5^{b}$ & $1600 \pm 69^{b}$ & 0.1 & $1010 \pm 60^{A}$ & $1030 \pm 120^{A}$ & 1.0 \\
\hline
\end{tabular}

3.3 Cadmium-induced accumulation of oxidatively damaged proteins was prevented by 205 proteasome increased activity

Protein carbonylation is considered a reliable parameter of oxidative stress (Shulaev y Oliver 2006). Also, the accumulation of oxidized proteins reflects the balance between their production and degradation, mainly by the $20 \mathrm{~S}$ proteasome activity. Under our experimental conditions, only $100 \mu \mathrm{M} C d$ incremented protein carbonyl group content along the whole root (Fig. 3).

A time-dependent analysis of three peptidase activities was assayed for $50 \mu \mathrm{M} C d$ treatment. As it is shown in Fig. 4, the metal incremented $20 \mathrm{~S}$ peptide hydrolyzing activities. At $72 \mathrm{~h}$, all of them were significantly increased in the Ap, and also $\mathrm{T}$ and $\mathrm{Q}$ in the Rt. Thus, the lack of carbonylated protein accumulation in maize roots subjected to $50 \mu \mathrm{M}$ treatment could be attributed to the increase in the activity of the $20 \mathrm{~S}$ proteasome, in a similar way to that previously described (Pena et al. 2007).

\subsection{Cadmium altered hormonal root homeostasis}

Cadmium enhanced IAA and ABA levels in the entire root tissue, whereas SA content increased only in the Rt portion (Table 4). IAA increments by $\mathrm{Cd}$ in rice roots were related to the overexpression of the biosynthetic genes OsASA2 and OsYUCCA1 (Ronzan et al. 2019). Also, it has been described that Cd affects not only IAA content but also its distribution, metabolism, and transport (Chmielowska-Bak et al. 2014), suggesting an eventual switch to an alternative morphogenic root program to counteract metal 
stress (Hu et al. 2013; Fattorini et al. 2017; Piacentini et al. 2020). Also, numerous reports indicate that exogenous application of IAA, as well as the IAA precursor indole-3-butyric acid (IBA), reduced Cd toxicity in plants (Agami y Mohamed 2013; Li et al. 2020b; Zhang et al. 2020; Zhou et al. 2020; Piacentini et al. 2020; Demecsová et al. 2020). However, more information is needed to know if endogenous IAA levels reached in maize root during $\mathrm{Cd}$ stress can induce a similar effect compared to that observed when IAA is exogenously added.

Table 4

Effect of Cd on hormone content. Extracts were obtained from root apex (Ap) and the remaining root tissue (Rt) of maize seedlings subjected to hydroponic culture without (control, C) or with 50 and $100 \mu \mathrm{M}$ of $\mathrm{CdCl}_{2}$ for $72 \mathrm{~h}$.

\begin{tabular}{|c|c|c|c|c|c|c|}
\hline \multirow{3}{*}{$\begin{array}{l}\text { Hormone } \\
\text { content } \\
\left(\mathrm{ng} \mathrm{g}^{-1}\right. \\
\mathrm{FW})\end{array}$} & \multicolumn{3}{|l|}{ Ap } & \multicolumn{3}{|l|}{ Rt } \\
\hline & \multirow[t]{2}{*}{ C } & \multicolumn{2}{|l|}{$\mathrm{CdCl}_{2}(\mu \mathrm{M})$} & \multirow[t]{2}{*}{ C } & \multicolumn{2}{|l|}{$\mathrm{CdCl}_{2}(\mu \mathrm{M})$} \\
\hline & & 50 & 100 & & 50 & 100 \\
\hline IAA & $10.8 \pm 1.7^{a}$ & $13.9 \pm 0.6^{b}$ & $20.5 \pm 0.7^{c}$ & $8.1 \pm 2.3^{A}$ & $23.6 \pm 2.6^{\mathrm{B}}$ & $36.3 \pm 5.7^{C}$ \\
\hline ABA & $\begin{array}{l}1.94 \pm \\
0.15^{\mathrm{a}}\end{array}$ & $\begin{array}{l}5.46 \pm \\
0.61^{b}\end{array}$ & $\begin{array}{l}3.49 \pm \\
0.12^{b}\end{array}$ & $\begin{array}{l}1.67 \pm \\
0.49^{A}\end{array}$ & $\begin{array}{l}8.65 \pm \\
0.34^{B}\end{array}$ & $\begin{array}{l}12.51 \pm \\
0.63^{\mathrm{B}}\end{array}$ \\
\hline SA & $9.3 \pm 0.2^{\mathrm{a}}$ & $17.3 \pm 1.6^{b}$ & $5.6 \pm 0.5^{c}$ & $16.6 \pm 1.7^{\mathrm{A}}$ & $25.6 \pm 1.6^{\mathrm{B}}$ & $25.0 \pm 1.0^{\mathrm{B}}$ \\
\hline GA20 & $3.1 \pm 0.3^{a}$ & $3.0 \pm 0.3^{a}$ & $4.9 \pm 0.1^{b}$ & $2.7 \pm 0.2^{\mathrm{A}}$ & $3.7 \pm 0.6^{A}$ & $6.4 \pm 0.2^{\mathrm{B}}$ \\
\hline GA7 & $146 \pm 9^{a}$ & $123 \pm 4^{b}$ & $125 \pm 6^{b}$ & $146 \pm 4^{\mathrm{A}}$ & $148 \pm 8^{A}$ & $156 \pm 3^{A}$ \\
\hline GA3 & $5.1 \pm 0.8^{a}$ & $3.7 \pm 0.3^{b}$ & $5.3 \pm 0.3^{a}$ & $3.3 \pm 0.6^{\mathrm{B}}$ & $5.8 \pm 0.7^{\mathrm{A}}$ & $3.9 \pm 0.7^{\mathrm{B}}$ \\
\hline GA4 & $\begin{array}{l}58.6 \pm \\
14.3^{\mathrm{a}}\end{array}$ & $25 \pm 2^{b}$ & $18.2 \pm 2^{c}$ & $\begin{array}{l}65.7 \pm \\
10.0^{\mathrm{A}}\end{array}$ & $38 \pm 10^{B}$ & $35 \pm 1.8^{B}$ \\
\hline JA & $\begin{array}{l}61.2 \pm \\
10.7^{a}\end{array}$ & $64.2 \pm 5.8^{a}$ & $38.4 \pm 2.5^{b}$ & $\begin{array}{l}82.8^{\AA} \\
12.1^{\mathrm{A}}\end{array}$ & $71.8 \pm 1.9^{\mathrm{A}}$ & $89.3 \pm 8.5^{\mathrm{A}}$ \\
\hline JA-Ile & $47.6 \pm 5.7^{a}$ & $9.5 \pm 2.8^{b}$ & $3.7 \pm 0.2^{b}$ & $57.9 \pm 9.6^{\mathrm{A}}$ & $14.8 \pm 0.3^{B}$ & $20.9 \pm 3.1^{B}$ \\
\hline $\begin{array}{l}\text { Data are } r \\
\text { treatment } \\
(P<0.05) \text {, }\end{array}$ & $\begin{array}{l} \pm \pm \text { SEM of } \\
\text { es represen } \\
\text { rding to Du }\end{array}$ & $\begin{array}{l}\text { ee independ } \\
\text { neans } \pm \text { SEN } \\
\text { ett's multiple }\end{array}$ & $\begin{array}{l}\text { experiment } \\
\text { ifferent lett } \\
\text { omparisons }\end{array}$ & $\begin{array}{l}\text { with three bio } \\
\text { within rows } \\
\text { st. }\end{array}$ & $\begin{array}{l}\text { gical replicat } \\
\text { dicate signifi }\end{array}$ & $\begin{array}{l}\text { per } \\
\text { ant differences }\end{array}$ \\
\hline
\end{tabular}

In plants, $A B A$ is recognized as a modulator of the adaptive abiotic stress responses (Cutler et al. 2010) and a key player in alleviating heavy metal stress (Hu et al. 2020). Hsu and Kao (2003) reported a close relationship between endogenous $A B A$ content and $\mathrm{Cd}$ tolerance in rice seedlings. Also, it was described that exogenous $\mathrm{ABA}$ application would partially relieve $\mathrm{Cd}$ toxic effects by increasing $\mathrm{GSH}$ and 
phytochelatins biosynthesis (Chen et al. 2016; Song et al. 2016), as well as restrict Cd uptake and distribution (Han et al. 2016; Shen et al. 2017; Tang et al. 2020).

SA increase in the Rt may be involved as a mechanism to counteract oxidative stress induced by $\mathrm{Cd}$. It has been well established that SA application improves plant acclimation to $\mathrm{Cd}$ excess by reducing the metal uptake and/or promoting plant antioxidant capacity (Popova et al. 2009; Hayat et al. 2010; Agami y Mohamed 2013; Shakirova et al. 2016; Guo 2019). In accordance, an Arabidopsis SA-deficient mutant resulted in negative effects on Cd tolerance, mainly due to the lowered GSH status (Guo et al. 2016).

Cadmium increased the root concentration of GA20, the precursor of the active form 13-hydroxylated GA3. Interestingly, the total root content of GA3 remained similar to the control at $100 \mu \mathrm{M}$ Cd but decreased in the Ap and increased in the Rt at $50 \mu \mathrm{M} \mathrm{Cd}$. On the other hand, the contents of non-13hydroxylated GA7 and GA4 were reduced under both Cd treatments. A similar drastic decrease in GA4 content was reported during copper stress (Matayoshi et al. 2020).

The mechanism by which metals affect GA4 homeostasis could involve interference with hormone biosynthesis but also with subsequent gibberellin transformations. Liu et al. (2015b) reported upregulation of two genes encoding GA2-oxidase, a major enzyme for deactivating bioactive gibberellins, in response to Cd stress.

The presence of $\mathrm{Cd}$ had a dramatic consequence on the active form JA-lle, whose concentration was strongly diminished under the metal treatment. JA-lle is considered the most metabolically active jasmonate (Fonseca et al. 2009), and, although the exogenous application of JA or methyl jasmonate (MJ) has been shown to alleviate Cd-toxic effects in plants (Singh y Shah 2014; Siddiqi y Husen 2019; Lei et al. 2020), little attention has been paid to Ile-JA regarding cadmium stress. Kurotani et al. (2015) suggested that deactivation of JA-lle results in enhanced salt tolerance in rice. It would be of special interest to evaluate the turnover of JA-lle in the context of Cd stress in future studies.

\section{Conclusion}

Maize seedlings exposed to Cd arrested root growth, and the entire primary root was found to be involved in redox and hormonal adjustments to trigger and/or to support defense mechanisms to cope with Cd stress. The integrated analysis of our experimental data shows that $\mathrm{Cd}$ addition decreases the root content of several essential nutrients, disrupts ASC homeostasis, and causes a strong decline in GA4 and JA-lle levels, along with root growth inhibition. Faced with the incapacity of maintaining ASC homeostasis, CAT and GPX would be alternative enzymatic defense lines for seminal roots to remove ROS excess during Cd stress. Finally, the $20 \mathrm{~S}$ proteasome seems to be a relevant defense component to cope with the oxidative damage generated by cadmium during this early stage of plant development.

\section{Declarations}

\section{Acknowledgments}


We thank Dr. Myriam S. Zawoznik for her helpful criticism and for improving the English. CLM is a Research Fellow at the UBA (Argentina). LBP and SMG are Career Investigators from CONICET (Argentina). Hormone measurements were performed at Servei Central d'Instrumentació Científica (SCIC) of Universitat Jaume I (Spain).

\section{Funding}

This work was supported by the Universidad de Buenos Aires (20020130100132BA UBACYT), and from Consejo Nacional de Investigaciones Científicas y Técnicas (PIP 0266).

\section{Conflicts of interest}

The authors have no conflicts of interest to declare that are relevant to the content of this article.

\section{References}

1. Abendroth L, Elmore RW, Boyer MJ, Marlay SK (2011) Corn growth and development. lowa State University, Agronomy Extension

2. Aebi H (1984) Catalase in vitro. Methods Enzymol 105:121-126. https://doi.org/10.1016/S00766879(84)05016-3

3. Agami RA, Mohamed GF (2013) Exogenous treatment with indole-3-acetic acid and salicylic acid alleviates cadmium toxicity in wheat seedlings. Ecotoxicol Environ Saf 94:164-171. https://doi.org/10.1016/j.ecoenv.2013.04.013

4. Anjum NA, Sharma P, Gill SS et al (2016a) Catalase and ascorbate peroxidase-representative $\mathrm{H}_{2} \mathrm{O}_{2}{ }^{-}$ detoxifying heme enzymes in plants. Environ Sci Pollut Res 23:19002-19029. https://doi.org/10.1007/s11356-016-7309-6

5. Anjum SA, Tanveer M, Hussain S et al (2015) Cadmium toxicity in maize (Zea mays L.): consequences on antioxidative systems, reactive oxygen species and cadmium accumulation. Environ Sci Pollut Res 22:17022-17030. https://doi.org/10.1007/s11356-015-4882-z

6. Anjum SA, Tanveer M, Hussain S et al (2016b) Osmoregulation and antioxidant production in maize under combined cadmium and arsenic stress. Environ Sci Pollut Res 23:11864-11875. https://doi.org/10.1007/s11356-016-6382-1

7. Asada K (1992) Ascorbate peroxidase -a hydrogen peroxide-scavenging enzyme in plants. Physiol Plant 85:235-241. https://doi.org/10.1111/j.1399-3054.1992.tb04728.x

8. Barabasz A, Klimecka M, Kendziorek M et al (2016) The ratio of $Z n$ to $C d$ supply as a determinant of metal-homeostasis gene expression in tobacco and its modulation by overexpressing the metal exporter AtHMA4. J Exp Bot 67:6201-6214. https://doi.org/10.1093/jxb/erw389

9. Bartoli CG, Casalongué CA, Simontacchi M et al (2013) Interactions between hormone and redox signalling pathways in the control of growth and cross tolerance to stress. Environ Exp Bot 94:7388. https://doi.org/10.1016/j.envexpbot.2012.05.003 
10. Bocova B, Huttova J, Liptakova L et al (2012) Impact of short-term cadmium treatment on catalase and ascorbate peroxidase activities in barley root tips. Biologia plantarum 56:724-728. https://doi.org/10.1007/s10535-012-0129-8

11. Bradford MM (1976) A rapid and sensitive method for the quantitation of microgram quantities of protein utilizing the principle of protein-dye binding. Anal Biochem 72:248-254. https://doi.org/10.1016/0003-2697(76)90527-3

12. Cai K, Yu Y, Zhang M, Kim K (2019) Concentration, source, and total health risks of cadmium in multiple media in densely populated areas, China. International Journal of Environmental Research Public Health 16:2269. https://doi.org/10.3390/ijerph16132269

13. Chang JD, Huang S, Yamaji N et al (2020) OsNRAMP1 transporter contributes to cadmium and manganese uptake in rice. Plant Cell Environ 43:2476-2491. https://doi.org/10.1111/pce.13843

14. Chen BC, Wang PJ, Ho PC, Juang KW (2017a) Nonlinear biotic ligand model for assessing alleviation effects of $\mathrm{Ca}, \mathrm{Mg}$, and $\mathrm{K}$ on $\mathrm{Cd}$ toxicity to soybean roots. Ecotoxicology 26:942-955. https://doi.org/10.1007/s10646-017-1823-2

15. Chen J, Yang L, Yan X et al (2016) Zinc-finger transcription factor ZAT6 positively regulates cadmium tolerance through the glutathione-dependent pathway in Arabidopsis. Plant Physiol 171:707-719. https://doi.org/10.1104/pp.15.01882

16. Chen X, Ouyang Y, Fan Y et al (2018) The pathway of transmembrane cadmium influx via calciumpermeable channels and its spatial characteristics along rice root. J Exp Bot 69:5279-5291. https://doi.org/10.1093/jxb/ery293

17. Chen Z, Tang Y-T, Zhou C et al (2017b) Mechanisms of Fe biofortification and mitigation of Cd accumulation in rice (Oryza sativa L.) grown hydroponically with Fe chelate fertilization. Chemosphere 175:275-285. https://doi.org/10.1016/j.chemosphere.2017.02.053

18. Chmielowska-Bak J, Gzyl J, Rucinska-Sobkowiak R et al (2014) The new insights into cadmium sensing. Front Plant Sci 5.. https://doi.org/10.3389/fpls.2014.00245

19. Chumbley CG, Unwin RJ (1982) Cadmium and lead content of vegetable crops grown on land with a history of sewage sludge application. Environmental Pollution Series B Chemical Physical 4:231237. https://doi.org/10.1016/0143-148X(82)90055-6

20. Coassin M, Ursini F, Bindoli A (1992) Antioxidant effect of manganese. Arch Biochem Biophys 299:330-333. https://doi.org/10.1016/0003-9861(92)90282-2

21. Cutler SR, Rodriguez PL, Finkelstein RR, Abrams SR (2010) Abscisic acid: emergence of a core signaling network. Annu Rev Plant Biol 61:651-679. https://doi.org/10.1146/annurev-arplant042809-112122

22. Dala-Paula BM, Custódio FB, Knupp EAN et al (2018) Cadmium, copper and lead levels in different cultivars of lettuce and soil from urban agriculture. Environ Pollut 242:383-389. https://doi.org/10.1016/j.envpol.2018.04.101

23. De Tullio MC, Jiang K, Feldman LJ (2010) Redox regulation of root apical meristem organization: Connecting root development to its environment. Plant Physiol Biochem 48:328-336. 
https://doi.org/10.1016/j.plaphy.2009.11.005

24. Demecsová L, Zelinová V, Liptáková L' et al (2020) Indole-3-butyric acid priming reduced cadmium toxicity in barley root tip via NO generation and enhanced glutathione peroxidase activity. Planta 252:46. https://doi.org/10.1007/s00425-020-03451-w

25. Dharma-Wardana MWC (2018) Fertilizer usage and cadmium in soils, crops and food. Environ Geochem Health 40:2739-2759. https://doi.org/10.1007/s10653-018-0140-x

26. Durgbanshi A, Arbona $V$, Pozo $O$ et al (2005) Simultaneous determination of multiple phytohormones in plant extracts by liquid chromatography-electrospray tandem mass spectrometry. J Agric Food Chem 53:8437-8442. https://doi.org/10.1021/jf050884b

27. Fattorini L, Ronzan M, Piacentini D et al (2017) Cadmium and arsenic affect quiescent centre formation and maintenance in Arabidopsis thaliana post-embryonic roots disrupting auxin biosynthesis and transport. Environ Exp Bot 144:37-48. https://doi.org/10.1016/j.envexpbot.2017.10.005

28. Fonseca S, Chini A, Hamberg M et al (2009) (+)-7-iso-Jasmonoyl-L-isoleucine is the endogenous bioactive jasmonate. Nat Chem Biol 5:344-350. https://doi.org/10.1038/nchembio.161

29. Foyer $\mathrm{CH}$, Noctor $\mathrm{G}$ (2011) Ascorbate and glutathione: The heart of the redox hub. Plant Physiol 155:2-18. https://doi.org/10.1104/pp.110.167569

30. Foyer $\mathrm{CH}$, Noctor $\mathrm{G}$ (2016) Stress-triggered redox signalling: What's in pROSpect? Plant Cell Environment 39:951-964. https://doi.org/10.1111/pce.12621

31. Gallego SM, Benavides MP (2019) Cadmium-induced oxidative and nitrosative stress in plants. Cadmium Toxicity and Tolerance in Plants. Elsevier, En, pp 233-274

32. Gallego SM, Pena LB, Barcia RA et al (2012) Unravelling cadmium toxicity and tolerance in plants: Insight into regulatory mechanisms. Environ Exp Bot 83:33-46. https://doi.org/10.1016/j.envexpbot.2012.04.006

33. Gill SS, Tuteja N (2010) Reactive oxygen species and antioxidant machinery in abiotic stress tolerance in crop plants. Plant Physiol Biochem 48:909-930. https://doi.org/10.1016/j.plaphy.2010.08.016

34. Godfray HCJ, Beddington JR, Crute IR et al (2010) Food security: the challenge of feeding 9 billion people. Science 327:812-818. https://doi.org/10.1126/science.1185383

35. Guo B (2019) Role of salicylic acid in mitigating cadmium toxicity in plants. Cadmium Toxicity and Tolerance in Plants. Elsevier, En, pp 349-374

36. Guo B, Liu C, Li H et al (2016) Endogenous salicylic acid is required for promoting cadmium tolerance of Arabidopsis by modulating glutathione metabolisms. J Hazard Mater 316:77-86. https://doi.org/10.1016/j.jhazmat.2016.05.032

37. Han Y, Wang S, Zhao N et al (2016) Exogenous abscisic acid alleviates cadmium toxicity by restricting $\mathrm{Cd}^{2+}$ influx in populus euphratica cells. J Plant Growth Regul 35:827-837. https://doi.org/10.1007/s00344-016-9585-2 
38. Hasanuzzaman M, Bhuyan MHMB, Anee TI et al (2019) Regulation of ascorbate-glutathione pathway in mitigating oxidative damage in plants under abiotic stress. Antioxidants 8:384. https://doi.org/10.3390/antiox8090384

39. Hayat Q, Hayat S, Irfan M, Ahmad A (2010) Effect of exogenous salicylic acid under changing environment: A review. Environ Exp Bot 68:14-25. https://doi.org/10.1016/j.envexpbot.2009.08.005

40. Hoagland DR, Aron DI (1950) The water-culture method for growing plants without soil. Agricultural Experimental Station of the University of California, Berkeley Circular 3:1-39

41. Hochholdinger F (2009) The maize root system: morphology, anatomy, and genetics. En: Handbook of Maize: Its Biology. Springer New York, New York, pp 145-160

42. Hsu YT, Kao CH (2003) Role of abscisic acid in cadmium tolerance of rice (Oryza sativa L.) seedlings. Plant Cell Environ 26:867-874. https://doi.org/10.1046/j.1365-3040.2003.01018.x

43. Hu B, Deng F, Chen $G$ et al (2020) Evolution of abscisic acid signaling for stress responses to toxic metals and metalloids. Front Plant Sci 11:909. https://doi.org/10.3389/fpls.2020.00909

44. Hu YF, Zhou G, Na XF et al (2013) Cadmium interferes with maintenance of auxin homeostasis in Arabidopsis seedlings. J Plant Physiol 170:965-975. https://doi.org/10.1016/j.jplph.2013.02.008

45. Huang D, Gong X, Liu Y et al (2017) Effects of calcium at toxic concentrations of cadmium in plants. Planta 245:863-873. https://doi.org/10.1007/s00425-017-2664-1

46. Huang X, Duan S, Wu Q et al (2020) Reducing cadmium accumulation in plants: structure-function relations and tissue-specific operation of transporters in the spotlight. Plants 9:223. https://doi.org/10.3390/plants9020223

47. Hussain B, Li J, Ma Y et al (2020) Effects of Fe and Mn cations on Cd uptake by rice plant in hydroponic culture experiment. PLOS ONE 15:e0243174. https://doi.org/10.1371/journal.pone.0243174

48. Jouili H, Bouazizi H, El Ferjani E (2011) Plant peroxidases: biomarkers of metallic stress. Acta Physiol Plant 33:2075-2082. https://doi.org/10.1007/s11738-011-0780-2

49. Kim M, Ahn J-W, Jin U-H et al (2003) Activation of the programmed cell death pathway by inhibition of proteasome function in plants. J Biol Chem 278:19406-19415. https://doi.org/10.1074/jbc.M210539200

50. Kleczkowski LA, Igamberdiev AU (2021) Magnesium signaling in plants. Int J Mol Sci 22:1159. https://doi.org/10.3390/ijms22031159

51. Kudo H, Kudo K, Uemura M, Kawai S (2015) Magnesium inhibits cadmium translocation from roots to shoots, rather than the uptake from roots, in barley. Botany 93:345-351. https://doi.org/10.1139/cjb-2015-0002

52. Kurotani K, Hayashi K, Hatanaka S et al (2015) Elevated levels of CYP94 family gene expression alleviate the jasmonate response and enhance salt tolerance in rice. Plant Cell Physiol 56:779-789. https://doi.org/10.1093/pcp/pcv006 
53. Laporte MA, Denaix L, Pagès $L$ et al (2013) Longitudinal variation in cadmium influx in intact first order lateral roots of sunflower (Helianthus annuus. L). Plant Soil 372:581-595. https://doi.org/10.1007/s1104-013-1756-3

54. Law MY, Charles SA, Halliwell B (1983) Glutathione and ascorbic acid in spinach (Spinacia oleracea) chloroplasts. The effect of hydrogen peroxide and of Paraquat. Biochem J 210:899-903. https://doi.org/10.1042/bj2100899

55. Lei GJ, Sun L, Sun Y et al (2020) Jasmonic acid alleviates cadmium toxicity in Arabidopsis via suppression of cadmium uptake and translocation. J Integr Plant Biol 62:218-227. https://doi.org/10.1111/jipb.12801

56. Li C, Liu Y, Tian J et al (2020a) Changes in sucrose metabolism in maize varieties with different cadmium sensitivities under cadmium stress. PLOS ONE 15:e0243835. https://doi.org/10.1371/journal.pone.0243835

57. Li Z, Zhu J, Wang Y et al (2020b) Effects of exogenous indole acetic acid on growth and cadmium accumulation of Cyphomandra betacea seedlings. Int J Environ Anal Chem 1-9. https://doi.org/10.1080/03067319.2020.1726336

58. Lin Z, Schneider A, Sterckeman T, Nguyen C (2016) Ranking of mechanisms governing the phytoavailability of cadmium in agricultural soils using a mechanistic model. Plant Soil 399:89-107. https://doi.org/10.1007/s11104-015-2663-6

59. Liu H, Zhang Y, Chai T et al (2013) Manganese-mitigation of cadmium toxicity to seedling growth of Phytolacca acinosa Roxb. is controlled by the manganese/cadmium molar ratio under hydroponic conditions. Plant Physiol Biochem 73:144-153. https://doi.org/10.1016/j.plaphy.2013.09.010

60. Liu K, Lv J, He W et al (2015a) Major factors influencing cadmium uptake from the soil into wheat plants. Ecotoxicol Environ Saf 113:207-213. https://doi.org/10.1016/j.ecoenv.2014.12.005

61. Liu T, Zhu S, Tang Q, Tang S (2015b) Genome-wide transcriptomic profiling of ramie (Boehmeria nivea L. Gaud) in response to cadmium stress. Gene 558:131-137.

https://doi.org/10.1016/j.gene.2014.12.057

62. Liu Y, Liu L, Qi J et al (2019) Cadmium activates ZmMPK3-1 and ZmMPK6-1 via induction of reactive oxygen species in maize roots. Biochem Biophys Res Commun 516:747-752. https://doi.org/10.1016/j.bbrc.2019.06.116

63. Lowry OH, Rosebrough NJ, Farr AL, Randal RJ (1951) Protein measurement with the Folin phenol reagent. J Biol Chem 193:265-275

64. Matayoshi CL, Pena LB, Arbona V et al (2020) Early responses of maize seedlings to Cu stress include sharp decreases in gibberellins and jasmonates in the root apex. Protoplasma 257:12431256. https://doi.org/10.1007/s00709-020-01504-1

65. Mazars C, Thuleau P, Lamotte O, Bourque S (2010) Cross-talk between ROS and calcium in regulation of nuclear activities. Mol Plant 3:706-718. https://doi.org/10.1093/mp/ssq024

66. Møller IM, Jensen PE, Hansson A (2007) Oxidative modifications to cellular components in plants. Annu Rev Plant Biol 58:459-481. https://doi.org/10.1146/annurev.arplant.58.032806.103946 
67. Nakano $\mathrm{Y}$, Asada $\mathrm{K}$ (1981) hydrogen peroxide is scavenged by ascorbate-specific peroxidase in spinach chloroplasts. Plant Cell Physiol 22:867-880.

https://doi.org/10.1093/oxfordjournals.pcp.a076232

68. Nan Z, Li J, Zhang J, Cheng G (2002) Cadmium and zinc interactions and their transfer in soil-crop system under actual field conditions. Science of The Total Environment 285:187-195. https://doi.org/10.1016/S0048-9697(01)00919-6

69. Nyström T (2005) Role of oxidative carbonylation in protein quality control and senescence. EMBO J 24:1311-1317. https://doi.org/10.1038/sj.emboj.7600599

70. Pal'ove-Balang P, Kisová A, Pavlovkin J, Mistríkl (2006) Effect of manganese on cadmium toxicity in maize seedlings. Plant Soil Environment 52:143-149. https://doi.org/10.17221/3358-PSE

71. Palusińska M, Barabasz A, Kozak K et al (2020) Zn/Cd status-dependent accumulation of Zn and Cd in root parts in tobacco is accompanied by specific expression of ZIP genes. BMC Plant Biol 20:37. https://doi.org/10.1186/s12870-020-2255-3

72. Pena LB, Azpilicueta CE, Gallego SM (2011) Sunflower cotyledons cope with copper stress by inducing catalase subunits less sensitive to oxidation. J Trace Elem Med Biol 25:125-129. https://doi.org/10.1016/j.jtemb.2011.05.001

73. Pena LB, Pasquini LA, Tomaro ML, Gallego SM (2007) 20S proteasome and accumulation of oxidized and ubiquitinated proteins in maize leaves subjected to cadmium stress. Phytochemistry 68:1139-1146. https://doi.org/10.1016/j.phytochem.2007.02.022

74. Piacentini D, Della Rovere F, Sofo A et al (2020) Nitric oxide cooperates with auxin to mitigate the alterations in the root system caused by cadmium and arsenic. Front Plant Sci 11: https://doi.org/10.3389/fpls.2020.01182

75. Piñeros MA, Shaff JE, Kochian LV (1998) Development, characterization, and application of a cadmium-selective microelectrode for the measurement of cadmium fluxes in roots of thlaspi species and wheat. Plant Physiol 116:1393-1401. https://doi.org/10.1104/pp.116.4.1393

76. Polge C, Jaquinod M, Holzer F et al (2009) Evidence for the existence in Arabidopsis thaliana of the proteasome proteolytic pathway: Activation in response to cadmium. J Biol Chem 284:3541235424. https://doi.org/10.1074/jbc.M109.035394

77. Popova LP, Maslenkova LT, Yordanova RY et al (2009) Exogenous treatment with salicylic acid attenuates cadmium toxicity in pea seedlings. Plant Physiol Biochem 47:224-231. https://doi.org/10.1016/j.plaphy.2008.11.007

78. Rahman A, Nahar K, Hasanuzzaman M, Fujita M (2016) Manganese-induced cadmium stress tolerance in rice seedlings: Coordinated action of antioxidant defense, glyoxalase system and nutrient homeostasis. CR Biol 339:462-474. https://doi.org/10.1016/j.crvi.2016.08.002

79. Redjala T, Sterckeman T, Louis Morel J (2010) Determination of the different components of cadmium short-term uptake by roots. J Plant Nutr Soil Sci 173:935-945. https://doi.org/10.1002/jpln.201000003 
80. Redjala T, Sterckeman T, Morel JL (2009) Cadmium uptake by roots: Contribution of apoplast and of high- and low-affinity membrane transport systems. Environ Exp Bot 67:235-242. https://doi.org/10.1016/j.envexpbot.2009.05.012

81. Rehman MZ ur, Rizwan M, Hussain A et al (2018) Alleviation of cadmium (Cd) toxicity and minimizing its uptake in wheat (Triticum aestivum) by using organic carbon sources in Cd-spiked soil. Environmental Pollution 241:557-565. https://doi.org/10.1016/j.envpol.2018.06.005

82. Ronzan M, Piacentini D, Fattorini L et al (2019) Auxin-jasmonate crosstalk in Oryza sativa L. root system formation after cadmium and/or arsenic exposure. Environ Exp Bot 165:59-69. https://doi.org/10.1016/j.envexpbot.2019.05.013

83. Santner A, Estelle M (2009) Recent advances and emerging trends in plant hormone signalling. Nature 459:1071-1078. https://doi.org/10.1038/nature08122

84. Seifikalhor M, Aliniaeifard S, Bernard F et al (2020) Y-Aminobutyric acid confers cadmium tolerance in maize plants by concerted regulation of polyamine metabolism and antioxidant defense systems. Sci Rep 10:3356. https://doi.org/10.1038/s41598-020-59592-1

85. Shakirova FM, Allagulova CR, Maslennikova DR et al (2016) Salicylic acid-induced protection against cadmium toxicity in wheat plants. Environ Exp Bot 122:19-28. https://doi.org/10.1016/j.envexpbot.2015.08.002

86. Sharma I, Ahmad P (2014) Catalase. En: Oxidative damage to plants. Elsevier, pp 131-148

87. Shen G, Niu J, Deng Z (2017) Abscisic acid treatment alleviates cadmium toxicity in purple flowering stalk (Brassica campestris L. ssp. chinensis var. purpurea Hort.) seedlings. Plant Physiol Biochem 118:471-478. https://doi.org/10.1016/j.plaphy.2017.07.018

88. Shulaev V, Oliver DJ (2006) Metabolic and proteomic markers for oxidative stress. New tools for reactive oxygen species research. Plant Physiol 141:367-372. https://doi.org/10.1104/pp.106.077925

89. Siddiqi KS, Husen A (2019) Plant response to jasmonates: current developments and their role in changing environment. Bulletin of the National Research Centre 43:153. https://doi.org/10.1186/s42269-019-0195-6

90. Singh I, Shah K (2014) Exogenous application of methyl jasmonate lowers the effect of cadmiuminduced oxidative injury in rice seedlings. Phytochemistry 108:57-66. https://doi.org/10.1016/j.phytochem.2014.09.007

91. Singh S, Singh A, Bashri G, Prasad SM (2016) Impact of Cd stress on cellular functioning and its amelioration by phytohormones: An overview on regulatory network. Plant Growth Regul 80:253263. https://doi.org/10.1007/s10725-016-0170-2

92. Sofo A, Scopa A, Nuzzaci M, Vitti A (2015) Ascorbate peroxidase and catalase activities and their genetic regulation in plants subjected to drought and salinity stresses. Int J Mol Sci 16:1356113578. https://doi.org/10.3390/ijms160613561

93. Song L, Huang SC, Wise A et al (2016) A transcription factor hierarchy defines an environmental stress response network. Science 354:aag1550-aag1550. https://doi.org/10.1126/science.aag1550 
94. Steinhorst L, Kudla J (2013) Calcium and reactive oxygen species rule the waves of signaling. Plant Physiol 163:471-485. https://doi.org/10.1104/pp.113.222950

95. Sterckeman T, Gossiaux L, Guimont $S$ et al (2018) Cadmium mass balance in French soils under annual crops: Scenarios for the next century. Sci Total Environ 639:1440-1452. https://doi.org/10.1016/j.scitotenv.2018.05.225

96. Sterckeman T, Redjala T, Morel JL (2011) Influence of exposure solution composition and of plant cadmium content on root cadmium short-term uptake. Environ Exp Bot 74:131-139. https://doi.org/10.1016/j.envexpbot.2011.05.010

97. Sterckeman T, Thomine S (2020) Mechanisms of Cadmium Accumulation in Plants. Crit Rev Plant Sci 39:322-359. https://doi.org/10.1080/07352689.2020.1792179

98. Tai H, Lu X, Opitz N et al (2016) Transcriptomic and anatomical complexity of primary, seminal, and crown roots highlight root type-specific functional diversity in maize (Zea mays L.). J Exp Bot 67:1123-1135. https://doi.org/10.1093/jxb/erv513

99. Tang RJ, Luan S (2017) Regulation of calcium and magnesium homeostasis in plants: from transporters to signaling network. Curr Opin Plant Biol 39:97-105. https://doi.org/10.1016/j.pbi.2017.06.009

100. Tang $Y$, Wang $L, X i e Y$ et al (2020) Effects of exogenous abscisic acid on the growth and cadmium accumulation of lettuce under cadmium-stress conditions. Int J Environ Anal Chem 100:720-731. https://doi.org/10.1080/03067319.2019.1639686

101. Thomine S, Wang R, Ward JM et al (2000) Cadmium and iron transport by members of a plant metal transporter family in Arabidopsis with homology to Nramp genes. Proceedings of the National Academy of Sciences 97:4991-4996. https://doi.org/10.1073/pnas.97.9.4991

102. Thor K (2019) Calcium-nutrient and messenger. Front Plant Sci 10:. https://doi.org/10.3389/fpls.2019.00440

103. Vanstraelen M, Benková E (2012) Hormonal interactions in the regulation of plant development. Annu Rev Cell Dev Biol 28:463-487. https://doi.org/10.1146/annurev-cellbio-101011-155741

104. Vardhan KH, Kumar PS, Panda RC (2019) A review on heavy metal pollution, toxicity and remedial measures: Current trends and future perspectives. J Mol Liq 290:111197. https://doi.org/10.1016/j.molliq.2019.111197

105. Vatehová Z, Malovíková A, Kollárová K et al (2016) Impact of cadmium stress on two maize hybrids. Plant Physiol Biochem 108:90-98. https://doi.org/10.1016/j.plaphy.2016.06.035

106. Wehr NB, Levine RL (2012) Quantitation of protein carbonylation by dot blot. Anal Biochem 423:241-245. https://doi.org/10.1016/j.ab.2012.01.031

107. Wu D, Yamaji N, Yamane M et al (2016) The HvNramp5 transporter mediates uptake of cadmium and manganese, but not iron. Plant Physiol 172:1899-1910. https://doi.org/10.1104/pp.16.01189

108. Xu X, Liu C, Zhao X et al (2014) Involvement of an antioxidant defense system in the adaptive response to cadmium in maize seedlings (Zea mays L.). Bull Environ Contam Toxicol 93:618-624. https://doi.org/10.1007/s00128-014-1361-z 
109. Ye N, Li H, Zhu G et al (2014) Copper suppresses abscisic acid catabolism and catalase activity, and inhibits seed germination of rice. Plant Cell Physiol 55:2008-2016.

https://doi.org/10.1093/pcp/pcu136

110. Yi Z, Lehto NJ, Robinson BH, Cavanagh J-AE (2020) Environmental and edaphic factors affecting soil cadmium uptake by spinach, potatoes, onion and wheat. Science of The Total Environment 713:136694. https://doi.org/10.1016/j.scitotenv.2020.136694

111. Zhang C, He Q, Wang M et al (2020) Exogenous indole acetic acid alleviates Cd toxicity in tea (Camellia sinensis). Ecotoxicol Environ Saf 190:110090.

https://doi.org/10.1016/j.ecoenv.2019.110090

112. Zhou J, Cheng K, Huang G et al (2020) Effects of exogenous 3-indoleacetic acid and cadmium stress on the physiological and biochemical characteristics of Cinnamomum camphora. Ecotoxicol Environ Saf 191:109998. https://doi.org/10.1016/j.ecoenv.2019.109998

\section{Figures}

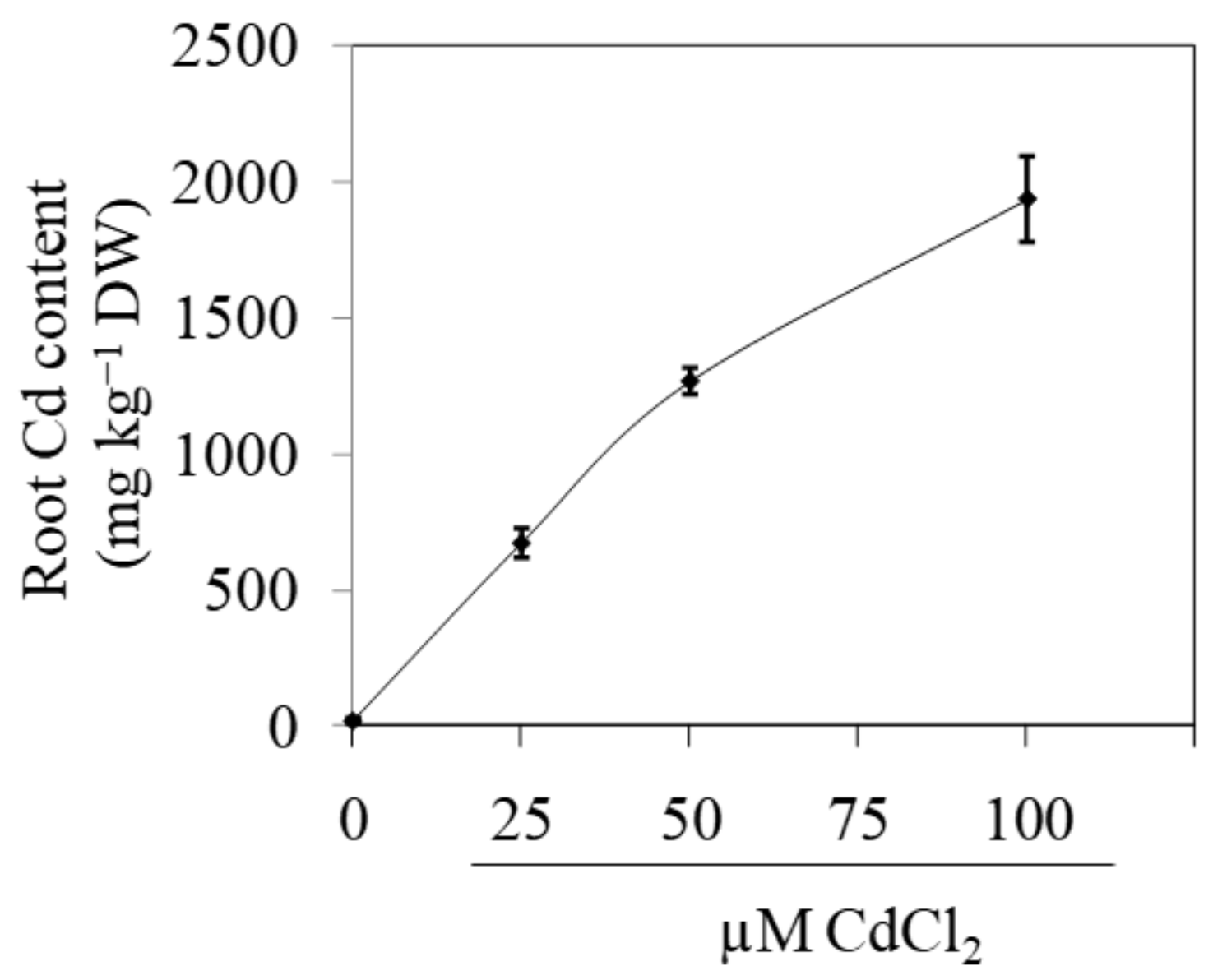

Figure 1

Root cadmium content. Maize seedlings were subjected to hydroponic culture without (control, C) or containing 50 and $100 \mu \mathrm{M}$ of $\mathrm{CdCl} 2$. After $72 \mathrm{~h}$ of treatment, roots were harvested and used for $\mathrm{Cd}$ 
determination. Data are means \pm SEM of five independent experiments, with three biological replicates per treatment. Different letters indicate significant differences $(P<0.05)$, according to Tukey's multiple range test.
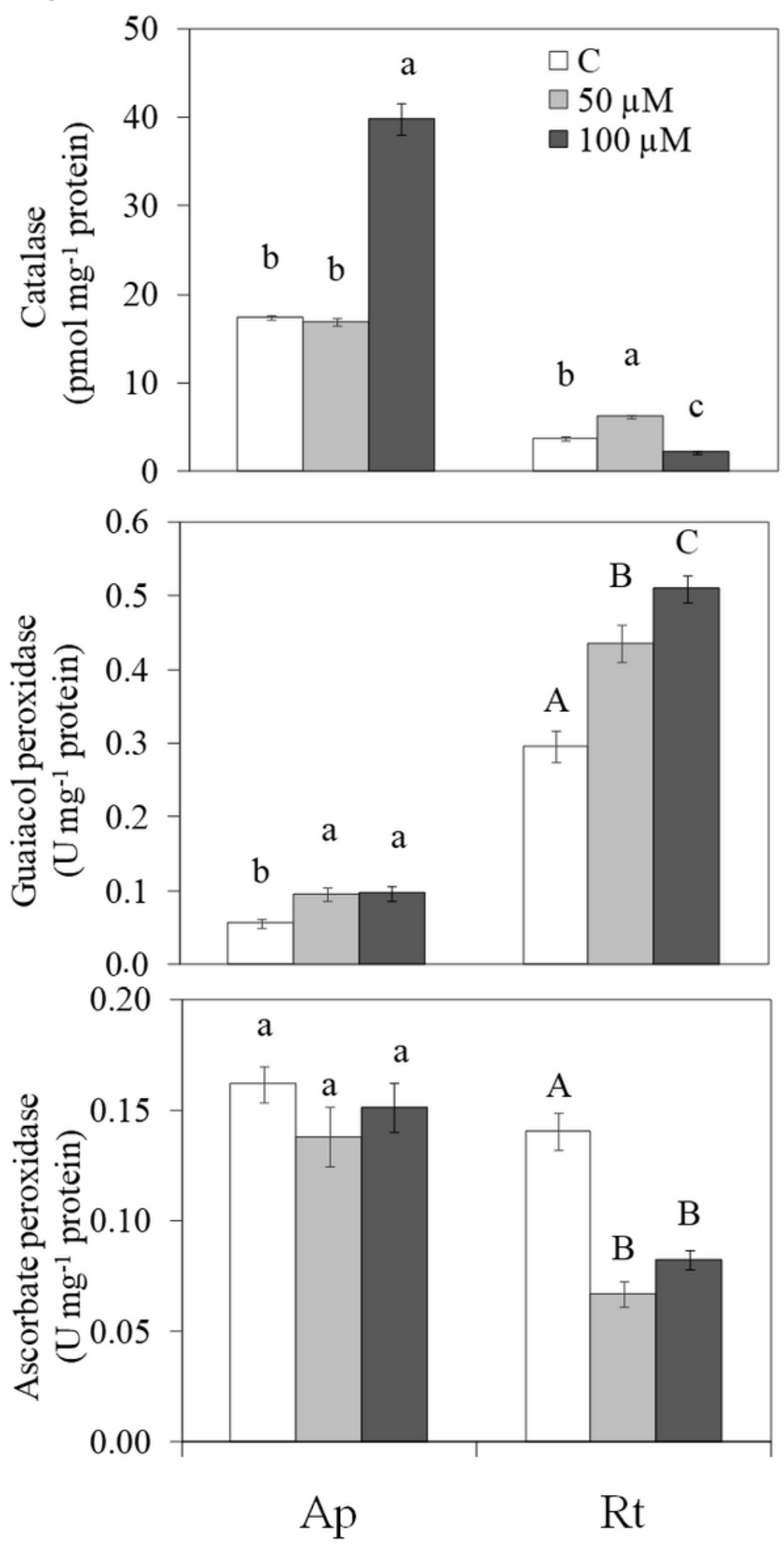

Figure 2

Effect of $\mathrm{Cd}$ on peroxidase activities. Maize seedlings were subjected to hydroponic culture without (control, C) or containing 50 and $100 \mu \mathrm{M}$ of $\mathrm{CdCl} 2$ for $72 \mathrm{~h}$. Determinations were performed on extracts 
obtained from the root apex (Ap) and the remaining root tissue (Rt). Data are representative of five independent experiments with three replicates. At least three technical replicates of each protein extract were used for these determinations. Bars represent means \pm SEM of five independent experiments, with three biological replicates per treatment. Different letters indicate significant differences $(P<0.05)$, according to Tukey's multiple range test.

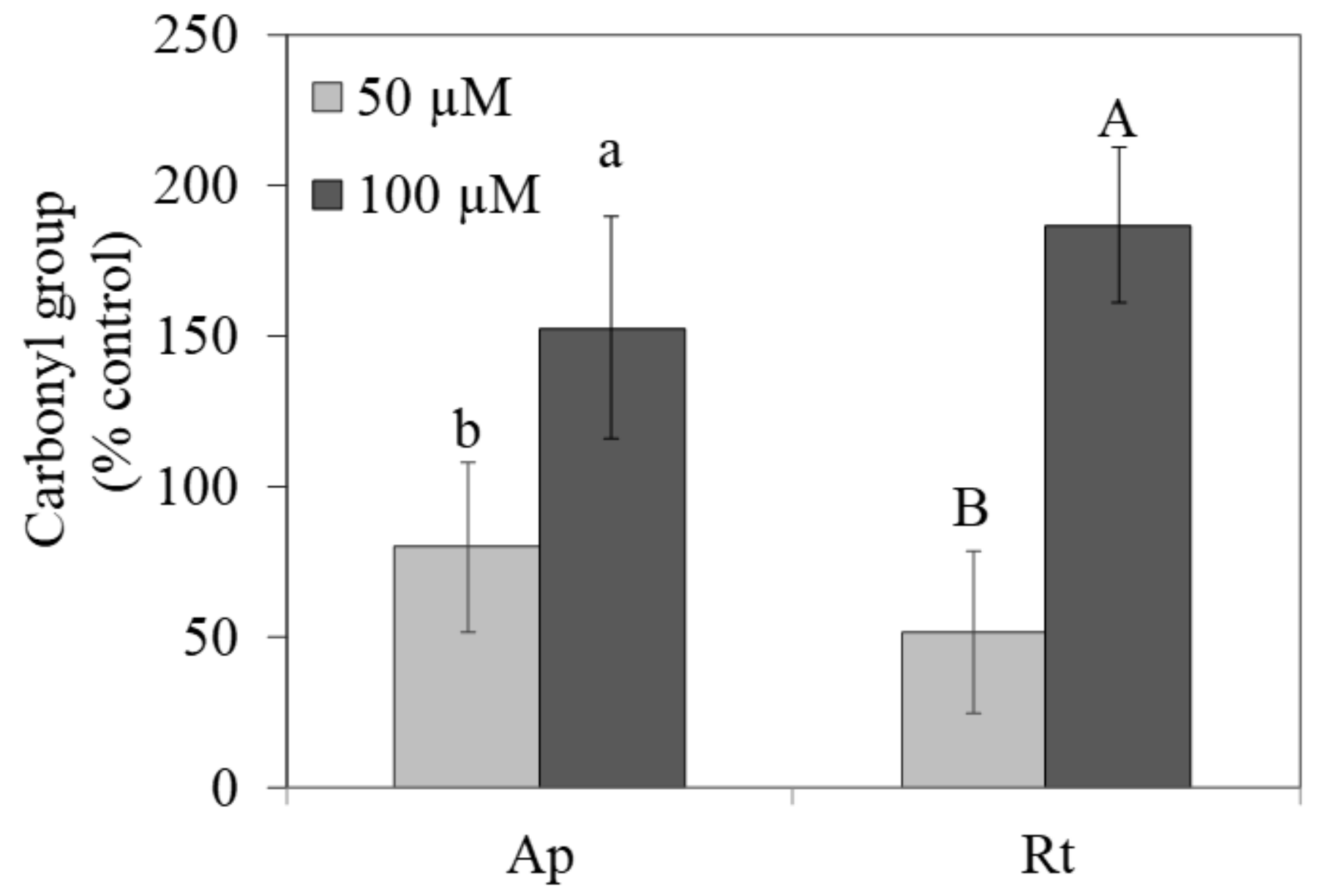

\section{Figure 3}

Effect of $\mathrm{Cd}$ on oxidative-damaged proteins. Maize seedlings were subjected to hydroponic culture without (control, C) or containing 50 and $100 \mu \mathrm{M}$ of $\mathrm{CdCl} 2$ for $72 \mathrm{~h}$. Root protein extracts obtained from root tips (At) and the remaining root tissue (Rt) were used to determine DNPH-derivatized proteins by dot blot. Membranes were photographed and analyzed with Gel-Pro software. Quantification of oxidized proteins is expressed in arbitrary units (assuming control value equal to 100), based on the absolute integrated optical density (IOD) of each dot. Bars represent mean \pm SEM. Different letters indicate significant differences respect to control at $P<0.05$, according to Tukey's multiple range test. 

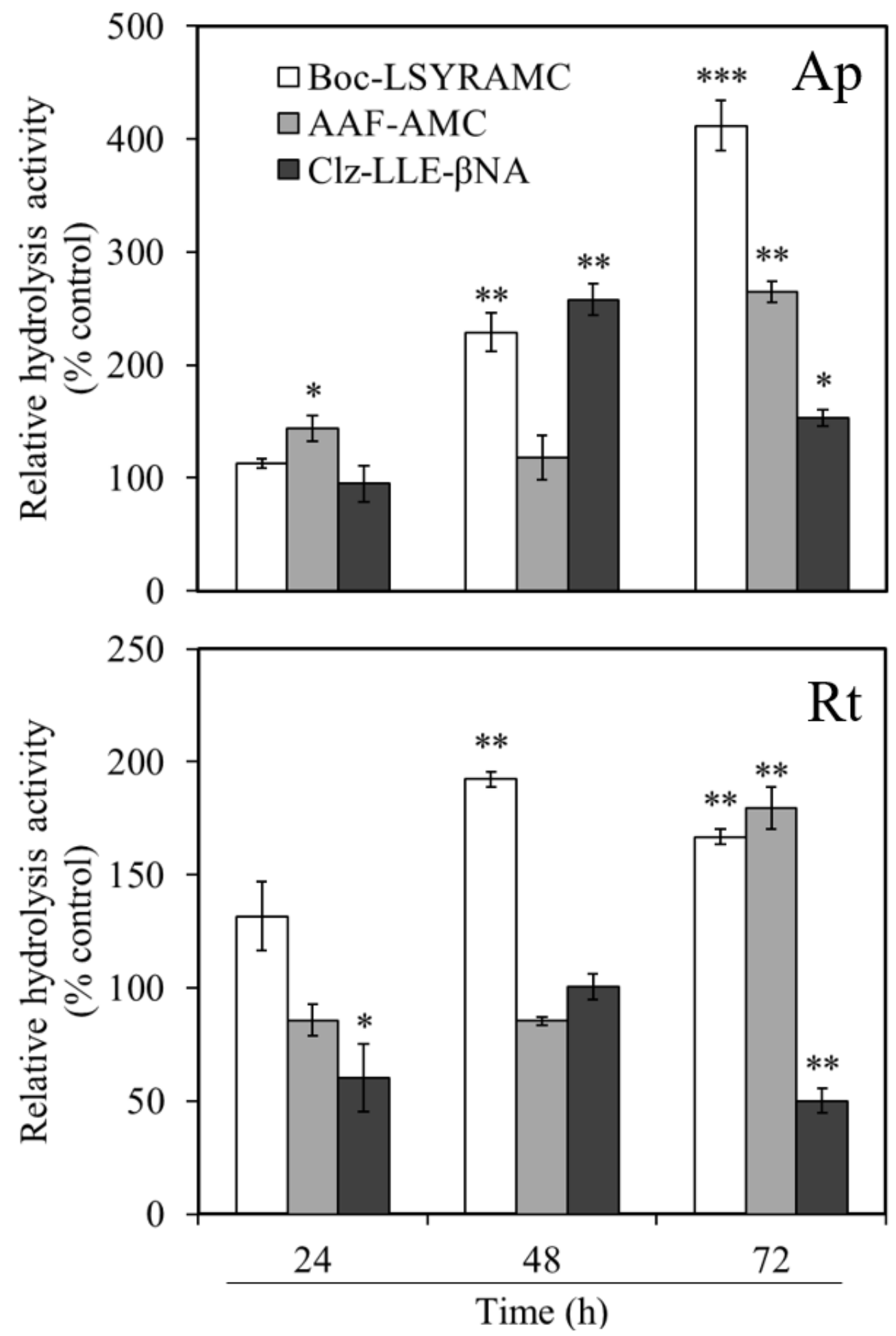

Figure 4

Effect of $\mathrm{Cd}$ on root proteasome proteolytic activities. Maize seedlings were subjected to hydroponic culture without (control, C) or with $50 \mathrm{CdCl} 2$ up to $72 \mathrm{~h}$. Trypsin-like, chymotrypsin-like, and peptidyl glutamyl peptide hydrolase (PGPH) proteasome activities were measured in roots extracts using three peptide substrates (Boc-LSYRAMC, AAF-AMC, and Clz-LLE-bNA, respectively) of the 20S proteasome in the absence or presence of the proteasome inhibitor MG132. Enzymatic activities were normalized for 
protein concentrations and expressed as percentages of activity present in the controls. Data are representative of five independent experiments with three replicates. At least three technical replicates of each protein extract were used for each enzyme activity determination. Bars represent mean values \pm SEM. Significant differences $* P<0.05,{ }^{*} P<0.01$ and $* \star * P<0.001$ were observed between control and treated plants at each time, according to Tukey's multiple range test. 